International Journal of Trade $\mathcal{E}$ Commerce-IIARTC

January-June 2020, Volume 9, No. 1 pp. 174-183

(C) SGSR. (www.sgsrjournals.co.in) All rights reserved

Double Blind Peer Reviewed/Referred International Indexed Journal

ISRA JIF: 6.318; COSMOS (Germany) JIF: 5.135; ISI JIF: 3.721; NAAS Rating 3.55

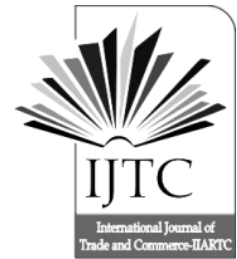

\title{
Board Structure and Agency Cost
}

\author{
Shubhi Agarwala ${ }^{*}$ and Archana Singh ${ }^{b}$ \\ aDepartment of Economics, Meerut College, Meerut, C.C.S. University, U.P. Pin code: 250002, \\ Email Id: shubhiagarwal1001@gmail.com \\ ${ }^{b}$ Department of Economics, Meerut College, Meerut, C.C.S. University U.P. Pin code: 250002, \\ Email Id: drarchnasingh@yahoo.com
}

\begin{abstract}
This research paper focuses to examine the role of board structure and corporate governance in eliminating agency cost in a sample of 30 firms selected from National Stock Exchange and Bombay Stock Exchange during the time period of 2007-19. This study uses return on assets to measure agency cost. This study applies multiple fixed effect of regression to analyze the data. The result findings also conclude that there is a positive impact of small board size, firm size, growth, independent directors and frequent board meetings on return on assets and helps in reducing agency cost but non-independent director does not make any impact and women director makes a negative impact on agency cost. (113WORDS).
\end{abstract}

Key Words: Agency cost, board size, corporate governance, directors and firm structure.
PAPER/ARTICLE INFO RECEIVED ON :19/04/2020 ACCEPTED ON: 29/06/2020

Reference to this paper should be made as follows:

Shubhi Agarwal and Archana Singh (2020), "Board Structure and Agency Cost", Int. J. of Trade and Commerce-IIARTC, Vol. 9, No. 1, pp. 174-183 
Board Structure and Agency Cost

Shubhi Agarwal and Archana Singh

\section{INTRODUCTION}

Corporate governance has attracted attention to the forefront of research because of the globalization of business practices and financial crises. The extraordinary interest in mechanisms of corporate governance and standards started because of failures in corporate firms around the global world. The United States Senate Permanent Investigation Sub-committee provided main findings of the leading role and liability of the Enron board of directors in the collapse of Enron and other cases. The leading cause liable for the failure of Enron includes excessive remuneration to company executives, lack of board independence, and indecorous conflict in the interests. Due to the collapse of Enron and other firms, this time duration has been called a historical period of corporate greed, extraordinary fraud, universal gatekeeper failure, and misgovernance of organization. The importance of corporate governance on the world economy has been recognized and acknowledged by the world with the starting of corporate scandals. In the corporate world, stakeholders have now followed all regulations of corporate governance when it is revealed managers performed fraudulent actions and self-interested behavior at the cost of principals, caused by the separation of ownership from management. Now, developing countries such as India have come to consider the importance of sound corporate governance. Domestic and international investors are unwilling to invest in companies that don't follow excellent corporate governance principles. The enhanced attention towards corporate governance has been influenced by the collapse of great corporations like WorldCom and Enron. To strengthen corporate governance practices, disclosure levels and transparency have made essential by countries. Lack of transparency, weak corporate governance practices, and corruption led to the collapse of financial institutions. Shareholders' confidence got reduced totally in both Public and Private corporations in the country because of weak governance practices. There should be an efficient system of corporate governance, which is considered as an essential component in running of day to day functioning of the company for the best interest of the shareholders. It helps to control the performance of the board members incorporated firm. The board of director has an important part to perform in the corporate governance system as their primary duty and responsibility is to supervise the management that ensures proper accountability to shareholders and other stakeholders. Since the board of directors is liable with the responsibility of monitoring the best interest of shareholders, they ought to have a higher interest in the appointment of directors to ensure that qualified, experienced, and educated directors are appointed. Individual firms have specified the profile requirements expected of their directors. Now the question arises whether characteristics of the board will influence the performance of the firm. Many researchers have depicted that corporate governance can be estimated through the size of the board, board women, CEO duality, education of board, working experience, outside directors, compensation, and block holders[1]. This research study will try to provide more to the existing literature by focusing on empirical evidence to the link between board structure and agency cost in India.

Corporate boards are the primary internal mechanism of corporate governance. It plays a significant role in monitoring the management and aligning the interests of principals with agents. Boards are accountable for control and ensure that financial controls are robust. Boards also point out the problems if anyone can implement a whistleblower function in a corporate firm. Boards may provide to the management practical guidelines and may even act to revise and endorse management proposals. Following the collapse of the Maxwell Publishing Group, BCCI, and Poly Peck in the UK, the ability of the corporate board has attracted the attention for monitoring of management. The boards are unable to monitor management due to insufficient 
tracking because of the consolidation of power by the administration. It has attracted the attention of reforms regarding the boardroom. Several global corporate governance codes of best practices such as the Cadbury Committee Report,1992; the Higgs Report, 2003 and the Smith Report of the same year in the United Kingdom; the 2000 NACD Blue Ribbon Commission Report and the 2002 Sarbanes-Oxley Act in the United States; the Toronto Stock Exchange Corporate Governance Guidelines of 1994 in Canada; and Australia's 1995 Bosch Report, the Australian Stock Exchange's (ASX) Principles of Good Corporate Governance and Best Practice Recommendations and CLERP advocated for boardroom reform in favor of independent board members[2]. The board of directors represents the internal mechanisms of governance, whose main objective to ensure that the interests of principals and agents are closely aligned and to remove or provide discipline to ineffective management. The most empirical literature depicts that the board plays a crucial role in conditions where agency costs between principals and agents may be intense. Still, there seems less evidence that overall performance is influenced by board composition. In recent times, several ways of increasing corporate governance are debited on the international platform. These ways of raising corporate governance have become the subject of discussion to academicians and the common public at large. It mainly focuses on the board characteristics, i.e., size of the board, diversity inboard, independence of the board, remuneration committee, and audit committee and ownership pattern of corporate firms.

\section{LiTERATURE REVIEW}

This section will provide a review of the literature on agency cost and board structure. The corporate governance mechanisms stress on the wealth maximization by mitigating agency problems existing in the corporate firms between principals and agents arising because there is a separation of ownership from management. There are mainly three approaches to board size. The first approach is concerned with the Agency Theory approach, which depicts a giant board is reasonable as compared to small board size as it is easy to monitor the management activities since more members will be able to review the actions of the management. The second approach is focusing on the Resource Dependency Theory, which shows a giant board that brings more chances for more connections to other organizations and, thus, access to external resources such as legitimacy, advice, and counsel. Despite this, there are certain severe limitations for having larger boards in corporate firms. Larger boards are less feasible and practical. Other significant limitations of having more members in the boards involve slow decision making, lack of communication and coordination, conflict of views, and lack of harmony among them that affect the efficacy and effectiveness of the board. The third approach is concerned with Stewardship Theory that favors the small size of boards. Small board size brings efficiency in making decisions at the appropriate time at the reasonable return of the projects. Small size boards usually have lesser conflict in opinions and ideas in making decisions of corporate organization. The small size of commissions is more efficient and effective. There is a definite link between the small size of the board and firm performance. The highest market value is attained easily with a small quantity of the board. Stock returns make a negative impact when the boards are more significant and positive effects when the boards reduce their size[3]. On an average basis, the board size of the corporate firm declined. Large active investors of corporate firms create a partial reason for the decline of board size. The market seemed more confident and worked efficiently if small boards are performing the monitoring work in an organization [4]. Theories of corporate governance were contrasting when applied for Australian's experience. There were three simple correlations 
Board Structure and Agency Cost

Shubhi Agarwal and Archana Singh

between board demographics and firm performance, i.e., the proportion of outside directors, CEO duality, and several interlocks. There is a significant impact of board composition on corporate performance[5]. There is a positive and meaningful relationship between management ownership and assets turnover ratio but does not exist any significant relationship between ownership concentration, board composition, and agency cost, as shown by taking Australian companies' sample [6].

The theoretical basis of board meetings frequency estimates the intensity of activities that board members perform and their monitoring quality and efficacy. Higher rates in board meetings can lead to qualitative monitoring and helps in improving firm performance, ceteris paribus. Frequent board meetings make board members better informed about the critical problems and aspects of the corporate firm so that they can make prompt decisions. Regularity in board meetings can become a hallmark for the efficient and robust director. On the other hand, there are opposite views on the frequency of board meetings. It is contended that these are not necessarily served in the best interests of principals. Time spent on regular meetings will not be used for healthy and meaningful discussions and opinions among themselves. Various formalities of meetings will absorb the precious time of debate and reduces the monitoring time by outside directors. These meetings are costly in terms of directors meeting fees, traveling expenses, and refreshment expenses that can directly make an inverse impact on corporate performance and thereby increases agency cost. There is a positive relationship between board meeting frequency and firm performance. Regular meetings of board members increase the capacity of the board for consultation, supervision, and management. Regular meetings of committees positively contribute to the sound financial performance of firms [7]. There is a negative relationship between the size of the corporate board and firm value, but there is a positive relationship between promoter ownership and firm value. If promoter ownership exceeds 40 percent, it can have a positive impact on firm value, and it will contribute towards interest alignment with that of the principal of the company [8]. There is a negative relation between board size and earning management but a positive relationship between CEO duality and drawing management. Large boards are more effective in monitoring a CEO's action, and the role of CEO and the Chairperson of the committee should be combined as to enhance the management's earning because CEO can reduce the effectiveness of the board and can create conflict between management and board that will reduce the earnings of management. There is a definite link between board activity and earnings of management, and it is reflected that the board meeting contributes positively towards increasing the profits of control [9].

\section{DATA AND METHOD}

This section reflects the research methodology, the research design, and sample design. This section also furnishes the study model, how it is estimated, and how it can be used to project the relationship between agency costs (return on assets) and board structure.

3.1. Research Design: This research study has an experimental research design.

Sample Design: Random sampling is used for the selective nature of corporate firms in this study, i.e., Information Technology companies. The lottery system method is used for the selection of Information Technology companies.

3.2. Target Population: The target population is all the listed companies in NSE and BSE. There are 30 companies.

3.3. Study Period: 2007-2019. 
3.4. Data Collection Method: This research uses secondary data obtained from annual reports through websites of corporate firms. Panel data is used in this research work.

Diagnostic Test: Correlation and regression model is used. Multiple variates of fixed-effect regression are used. STATA software is used for analyzing the results. In this study, the dependent variable is agency cost, and independent variables are the size of the board, several independent directors, non-independent directors, and women director about total board members, firm size, firm growth, and board meeting frequency.

3.5. Dependent Variable- Agency cost is the dependent variable. I use return on assets for measuring agency costs in this study because it is a sound firm economic performance indicator. It is an excellent accounting performance measure. Return on Assets is defined as the ratio of Earnings before Interest and Taxes (EBIT) and the book value of total assets. A higher return on assets ratio tells that companies are efficient in using their assets, whereas a low return on asset ratio tells poor asset management. Return on asset ratio is the best indicator to depict the relationship between principals and agents as they have conflict in their interests, and it measures how efficiently agents are using the assets of the company to increase shareholder's value. It is defined as

Return on Asset Ratio = EBIT/ book value of total assets.

3.6 Independent Variables- The variables are the chief estimator of agency cost that can quickly reflect board structure and corporate governance mechanisms with the following: Board Size: It is the natural logarithm of total number board members; Independent Directors: An independent director can be called as a non-executive director of a company. Independent directors help increase the corporate credibility and governance standards; Non- Independent Directors: A nonindependent directors are the ones who are not an independent director; Women Directors; Firm size: is measured by the natural logarithm of total closing assets; Firm Growth: is regulated by the percentage of annual change in sales and board meeting frequency: total number of board meetings held during the period.

\section{HYPOTHESIS}

H1: Increase in firm size reduces agency cost.

H2: Agency costs will be reduced with an increase in firm growth. H3: Small board size reduces agency costs.

H4: An inverse relationship exists between the proportion of independent directors and agency costs.

H5: Higher non-independent directors on the board reduces agency costs.

H6: Higher women director in the board cuts agency cost.

H7: Increase in the frequency of board meetings reduces agency costs.

\section{MODEL}

To examine the link between agency cost and all independent variables, a multivariate fixed effect regression model is applied. The model can be explained here:

Agency cost $($ ROA $)=\alpha+\beta 1($ NLTA ROA $)+\beta 2($ GROWTH ROA $)+\boldsymbol{\beta} 3($ NLBM ROA $)+\boldsymbol{\beta} 4$ (ID/TBM ROA) + $\boldsymbol{\beta 5}$ (NID/TBM ROA) + $\boldsymbol{\beta} 6$ (WD/TBM ROA) + $\boldsymbol{\beta} 7$ (BMF ROA) + e ROA,

where agency cost ROA $=$ the dependent variable of the study, ROA represents return on asset ratio for firm $i$ at period $t, a=$ the intercept, Independent variables include NLTA depicts natural $\log$ of total closing assets that tells firm size, GROWTH depicts firm growth, NLBM represents natural log of board members, ID/TBM depicts number of independent directors / total board 
members, NID/TBM depicts the number of non- independent directors / total board members, WD/TBM depicts the number of women director/ total board members and BMF represents board meeting frequency

\section{ANALYSIS AND RESUlts}

Descriptive Statistics (Table-1)

\begin{tabular}{|l|c|c|c|c|c|}
\hline & Mean & Median & $\begin{array}{c}\text { Standard } \\
\text { Deviation }\end{array}$ & Minimum & Maximum \\
\hline NID/TBM & 0.642 & 0.625 & 0.2761 & 0.090 & 2 \\
WD/TBM & 00.077 & 0.0769 & 0.086 & 0 & 0.333 \\
Growth & 14.313 & 9.677 & 25.922 & -40.226 & 182.89 \\
NLTA & 07.212 & 7.010 & 01.738 & 03.901 & 11.573 \\
NLBM & 02.208 & 2.197 & 00.261 & 01.609 & 2.708 \\
ID/TBM & 0.5597 & 0.545 & 0.126 & 00.25 & 1 \\
BMF & 06.308 & 6 & 01.746 & 4 & 12 \\
ROA & 0.1535 & 0.132 & 00.173 & -0.789 & 1.339 \\
\hline
\end{tabular}

Correlation Matrix (Table 2)

\begin{tabular}{|l|c|c|c|c|c|c|c|c|}
\hline & NID/TBM & WD/TBM & Growth & NLTA & NLBM & ID/TBM & BMF & ROA \\
\hline NID/TBM & $\mathbf{1}$ & & & & & & & \\
WD/TBM & 0.042 & $\mathbf{1}$ & & & & & & \\
Growth & 0.015 & -0.087 & $\mathbf{1}$ & & & & & \\
NLTA & -0.165 & 0.175 & 0.027 & $\mathbf{1}$ & & & & \\
NLBM & -0.374 & -0.038 & 0.046 & 0.439 & $\mathbf{1}$ & & & \\
ID/TBM & 0.226 & 0.318 & 0.088 & 0.104 & -0.176 & $\mathbf{1}$ & & \\
BMF & 0.031 & 0.143 & -0.025 & 0.0242 & -0.108 & 0.190 & $\mathbf{1}$ & \\
ROA & -0.000 & -0.110 & 0.123 & 0.128 & 0.120 & 0.117 & -0.02 & $\mathbf{1}$ \\
\hline
\end{tabular}

Table 3

\begin{tabular}{|c|c|c|c|}
\hline Multiple R & R Square & Adjusted R Square & Standard Error \\
\hline 0.6905 & 0.4768 & 0.4650 & 0.1692 \\
\hline
\end{tabular}

Table 1 above provides detailed statistical results on the dependent and independent variables that were used in the empirical analysis of this study. The research findings show that the mean value of the ratio of non- independent directors to total board members is 0.6429 with a maximum of 2 and a minimum of 0.0909, standard deviation, and median 0.27611 and 0.625 , respectively. The table also shows that the mean value of the ratio of women directors in the total board members is 0.0770 with a minimum of 0 and a maximum of 0.3333 , standard deviation, and median 0.0860 and 0.0769 , respectively. The findings depict that on average firm growth (measured by taking a percentage of annual changes in sales) in the Indian IT companies is 14.31 with a maximum of 182.89 and a minimum of -40.22 , standard deviation, and median are 25.92 and 9.67 respectively. The mean value of firm size (measured by taking the natural log of total assets) is 7.21 , with a minimum of 3.90 and a maximum of 11.57 , its median is 7.01 , and the standard deviation is 1.73 . The findings indicate that, on average, board size (measured by taking the natural log of board members) in the Indian IT companies is 2.20 with a maximum of 2.70 and a minimum of 1.60, standard deviation, and median are 0.2619 and 2.19 , respectively. The mean value of the number of independent directors to total board members is 0.5597 with a minimum of 0.25 and a maximum of 1 , its median is 0.5454 , and the standard deviation is 0.1268 . The mean 
value of frequency of board meetings is 6.308, with a minimum of 4 and a maximum of 12, its median is six, and the standard deviation is 1.746 . The agency cost is measured by return on assets having average value, median, standard deviation $0.1535,0.1324,0.1738$, respectively, with a minimum of -0.7890 and a maximum of 1.3394 .

As per the table 2, there is a slight degree of positive correlation relationship between dependent variable which is measured by return on assets that depicts agency cost and independent variables which are regulated by firm growth, firm size (NLTA), size of board and number of independent directors, non- independent directors and women directors to a total number of board members and board meetings frequency. It is depicted in the table mentioned above that there exists a negligible relationship between agency cost and all independent variables.

The results of multivariate regression analysis are presented in table 3, with return on assets as the dependent variable and firm growth, firm size, board size, frequency of board meetings, and several independent directors, non-independent directors, women directors to total numbers of board members as independent variables. This model depicts that there is a moderate degree of a positive correlation between return on assets (dependent variable) and all independent variables as multiple $\mathrm{R}$ is 0.6905 . The model as a whole is significant in explaining variation in the dependent variable. R-square is 0.4768 , which means that the independent variables explain $47 \%$ variation in the dependent variable, i.e., return on assets. It depicts that growth of the firm, size of the firm, size of board and number of independent directors, number of non- independent directors, women director, and frequency of board meetings explain the $47 \%$ variation in return on assets. As per the results depicted, there is a positive correlation among them. Increase in all independent variable except non- independent and women director impact positively to the reduction in agency cost measured by return on assets up to 47 percent.

\section{SPecific Variable Discussion}

a. Board Size: The coefficient of board size is -1.6584 . It shows that the board size and return on assets are negatively linked. The results show that $t=-2.3088$ and $p=0.04$ are statistically significant. Hence the research concludes that board size has a negative and significant impact on return on assets. It depicts that if there is a decline in return on assets, then agency costs will be increased. The hypothesis is accepted. The result findings are consistent with the Stewardship Theory but discards Agency and Resource Dependency Theory. It gives stresses on smaller board size that brings lesser clashes between principal and agents and helps in making prompt decisions in the organization as several opinions and ideas providing members are lower on the board. If the size of the board is big, individual directors will be less concerned with the monitoring of management. Large board size also adds to cost to the corporation in terms of fees and remunerations. If these costs are not matched with profitgenerating ideas, plans, efficient monitoring of management, and fraud prevention, the financial performance of corporate firms will decline as the board size increases.

b. Firm Size: The coefficient of firm size is 1.7892. The result tells the link between firm size and returns on assets is direct with $\mathrm{t}=2.3545$ and $\mathrm{p}=0.02$ that are statistically significant. This research concludes that there exists a positive relationship between firm size and return on assets, and it will contribute positively to reduce agency cost. If the size of the firm is large, it starts generating economies of scale. It improves efficiency in the achievement of organizational goals. It will lead to the division of labor and specialization in IT companies. It 
helps in capturing the market share, and the large size of firms also develops brand image and creditability.

c. Firm Growth: The coefficient of firm growth is 2.4562. It depicts that there is a positive relationship between firm growth and returns on assets. The results describe that $t=3.258$ and $p=0.005$ indicate that the link between firm growth and return on assets is statistically significant. This study concludes that firm growth is helpful in mitigating agency costs.

d. Independent Directors: The coefficient of the ratio of independent directors to the board $(0.500040)$ shows that there is a direct relationship between the number of independent directors to board and return on assets. It implies that there is a positive relationship between independent directors and returns on assets, or we can say independent directors play a crucial role in eliminating agency costs and improving the financial performance of corporate firms. The results tell that $\mathrm{t}=0.8843$ and $\mathrm{p}=0.0065$ are statistically significant. This result finding supports the Agency Model that focuses on monitoring function by agents. Agency Model stresses that more independent director on the board will be included to increase monitoring of management and makes them accountable to act in the best interest of the principal. Hence, it can contribute to improvements in the financial performance of the corporate firm. Those boards having a large number of independent directors are considered to be more dynamic, diverse about skills, expertise, nationality, experience, and contribute positively towards the attainment of organizational goals more efficiently and effectively of the company and hence improves performance. The independent directors also serve as a 'watchdog' and monitor every function and minutely measure every decision and take actions at the appropriate time that adds to the financial performance of IT companies in India

e. Non- Independent Directors: The coefficient of the proportion of independent directors to total board members is -0.0137 . The result tells that $p=0.67$, which means the hypothesis is rejected. This study concludes that a portion of non-independent directors on the board does not make a positive impact on reducing agency costs. Decisions of non-independent directors are influenced by the principals or owners of corporate firms. They can't freely monitor and can take investment projects related decisions promptly and on due time as they are nonindependent directors of the company.

f. Women Director: The coefficient of the proportion of women director to total board members is -0.3342 . The study tells that $t=-2.93 p=0.003$ means that the hypothesis is accepted. This study concludes that the proportion of women directors on the board makes a negative impact on return on assets. It also implies that women directors on the board do not reduce agency costs. There is a negative relationship between financial performance and gender diversity. The reason behind the negative correlation between them could be furnished in the performance measurement argument and the limited number of women directors on the board of a corporate firm. The appointment of women director in the commission of corporate firms is a formality to create an image of women empowerment and tries to furnish the copy of gender sensitivity in the company. The appointment of women is merely for window dressing in the company to maintain and lead a good reputation in the global environment[10].

g. Board Meeting Frequency: The coefficient of the proportion of the frequency of board meetings is 0.1500 . The study tells that $p=0.0003$ means that the hypothesis is accepted. This study concludes that the increase in the rate of board meetings make a positive impact on increasing return on assets and thereby helps in reducing agency cost. This result supports 
the proponents who state that frequent board meetings make them better informed about the critical problems and aspects of corporate firms so that they can make prompt decisions. Regularity in board meetings can become a hallmark for the efficient and robust director.

\section{CONCLUSION}

This research study focuses on investigating the relationship between board structure and agency cost. The result findings depict that IT companies are moving towards effective governance mechanisms for reducing agency costs. This study gave recommendations about the proper size of the board to enhance board effectiveness. The result shows that there is a negative relationship between the size of the board and the return on assets. Smaller size boards perform better when compared with large size boards. The small size of the board will make better strategic decisions as it can make prompt decisions without any delay, reduction in the difference of ideas, strategies, and interest among them[11]. The research study also stresses the appointment of more independent directors into board members so that independence of the board can be increased easily. The result findings also depict that more independent directors will contribute positively to enhance the return on assets. This study also furnishes that more independent directors on the board will monitor the management more efficiently. The results conclude that women director makes a negative impact on reducing agency cost. Still, firm size and firm growth help in reducing agency costs of IT corporate firms, but non-independent directors don't make any impact on agency costs. The result also furnishes that the frequency of board meetings has a positive influence on firm performance and helps in mitigating agency costs.

\section{LiMitaTiONS OF THE STUDY}

The availability of literature in India on corporate governance, board structure, and agency cost is limited. Those which are available have certain shortcomings in terms of the size of samples used and the number of corporate governance mechanisms used. As data is collected through annual reports, it may not be an accurate representation of the company's state of affairs and performance. It is a matter of common understanding that accounting profits are subject to manipulation. This research study includes the study period from 2007-2019, so it takes into account some global recessionary impact on the overall variables which are taken into consideration. I, therefore, recommend that more intensive study can be conducted for further research purposes.

\section{REFERENCES}

[1]. Adams, R. B., Ferreira. D. (2007). A Theory of Friendly Boards. Journal of Finance, Vol. 62, pp. 217-250.

[2]. Daghsni O, Zouhayer M, Mbarek KBH (2016), Earnings Management and Board Characteristics: Evidence from French listed firms. Arabian Journal of Business Management Review 6: 249.

[3]. Kiel, G. C., \& Nicholson, G. J. (2003). Board composition and corporate performance: How the Australian experience informs contrasting theories of corporate governance. Corporate Governance: An International Review, Vol. 11, Issue 3, pp. 189-205.

[4]. Kumar, N. and Singh, J.P. (2013), Effect of board size and promoter ownership on firm value: some empirical findings from India. Corporate Governance: The International Journal of Business in Society, Vol. 13, Issue 1, pp. 88 - 98. 
[5]. Ntim, C. G., \&Osei, K. A. (2011). The Impact of Corporate Board meetings on Corporate Performance in South Africa. African Review of Economics and Finance, Vol. 2, Issue 2.

[6]. Parker H. (2006) Governing the Corporation, Business the Ultimate, A \& B Black Publishers Ltd, 2006.

[7]. Rashid, A. (2018). Board Independence and firm performance: Evidence from Bangladesh. Future Business Journal, Vol. 4, Issue1, pp. 34-49.

[8]. Truong, T., (2006), Corporate Boards, Ownership, and Agency Costs: Evidence from Australia. The Business Review, Cambridge; Summer, Vol. 5, Issue 2, pp. 163-167

[9]. VO, D., and Pham, T.(2013). Corporate governance and firm performance: Empirical evidence from Vietnam. Journal of Financial Economics, 78, pp. 210-226.

[10]. Wu, Y. (2000). Honey, CalPERS Shrunk the Board. Working Paper, University of Chicago.

[11]. Yermack, D. (1996). Higher Market Valuation of Companies with a Small Board of Directors. Journal of Financial Economics, Vol. 40, Issue 2, pp. 185-211. 